\title{
Population AND Habitat Ecology of DeER ON DEVILS TOWER NATIONAL MONUMENT
}

\author{
GREG W. MCDANIEL • EVELYN H. MERRILL \\ DEPARTMENT OF ZOOLOGY AND PHYSIOLOGY \\ FRED G. LINDZEY $\downarrow$ WYOMING COOPERATIVE FISH AND WILDLIFE RESEARCH UNIT \\ UNIVERSITY OF WYOMING $\bullet$ LARAMIE
}

\section{$-\quad$ INTRODUCTION}

White-tailed (Odocoileus virginianus) and mule deer (O. hemionus) currently use Devils Tower National Monument and adjacent private agricultural lands year round or migrate from the Monument to other areas. In 1989, a game fence was constructed on the west and north borders of the Monument. Enclosure of the Monument by additional fencing could alter habitat use of deer substantially and create many of the problems associated with island reserves. National Park Service management policy directs the Monument to predict changes in the natural resources under its stewardship. Because current deer use of the Monument is not well documented, the Department of Zoology and Physiology and the Wyoming Cooperative Fish and Wildlife Research Unit, in cooperation with the Devils Tower National Monument, initiated a study in June 1990 to document current population numbers and habitat ecology of white-tailed and mule deer on the Monument as a baseline for monitoring long-term changes in the deer herd.

\section{$\checkmark \quad$ STUdUY OBJECTIVES}

(1) Evaluate methods to estimate seasonal deer densities on the Monument.
(2) Determine seasonal movement patterns and time spent on and off the Monument by radiocollared deer.

(3) Determine habitat selection patterns of deer on the Monument relative to forage, snow, and cover characteristics.

(4) Estimate the nutritional carrying capacity of the Monument for deer.

\section{$\downarrow \quad$ METHODS AND RESULTS}

\section{POPULATION ESTIMATES}

The cost-effectiveness of 3 population monitoring methods are currently being evaluated. Each month, 12 transects have been walked across the Monument. Observers recorded the number of deer within a group, distance and compass bearing to a group, and plotted the location of the group on an aerial photo. A group of deer was defined as an aggregation of deer within $30 \mathrm{~m}$ of each other. Estimates of deer density were calculated using the computer program TRANSECT. Estimates of the number of white-tailed deer using the Monument during the fall of 1990 and spring of 1990 were 107 and 204, respectively. Estimates of the number of 
mule deer are unreliable and imprecise because of the low densities of deer on the Monument. In October, we will increase the number of transects to 16 per month to try to increase the precision of our estimates.

Pellet group counts have been conducted twice on the Monument since the initial clearing of 44 plots in the fall of 1990. Thirty additional plots were established and cleared in the spring of 1991. Pellet group counts indicated that approximately $205 \pm 93$ deer used the Monument on average during the period November 1990-April 1991. Counts for the period May-October 1991 have not yet been analyzed. Our initial counts indicate that 117 pellet group plots would be needed to obtain a relative precision of $20 \%$ and $>400$ plots would be needed to obtain a precision level of $10 \%$. An additional 50 plots $(n=125)$ were cleared in October of 1991 and will be counted in the spring of 1991 .

Our third total deer count was conducted on the Monument on 19 October 1991 using 51 people. Forty-three "drivers" (approximately $55 \mathrm{~m}$ apart) walked in a line from the northern border of the Monument southward counting deer as they passed through the line. The remaining participants were stationed along the Monument's borders and counted deer as they moved across the borders. One hundred and fifty eight white-tailed deer, 53 mule deer and 2 unclassified deer were counted. This number of deer is somewhat higher than the 117 white-tailed deer, 63 mule deer, and 2 unclassified deer counted the previous fall with 34 participants. In the spring of 1991, 97 white-tailed deer, 2 mule deer and 2 unclassified deer were counted on the drive count using 65 participants.

Some deer are displaced from the Monument by the drive but return shortly afterwards. For example, prior to the drive on October 19, all but one of the radio-collared deer $(n=12)$ were located on the Monument. About half of the does were displaced off the Monument after the drive but returned to the Monument within 3-4 days after the drive.

\section{CAPTURE, MOVEMENTS AND HABITAT USE OF RADIO-COLLARED DEER}

During July 1991, 2 adult white-tailed does and 2 adult mule deer does were radio-collared. Thus, twenty-six deer have been radio-collared during the study. Seven of the collared deer have died naturally or were killed by hunters. An additional 7 collared deer have either moved off the Monument or their transmitters have failed. Three of these deer were white-tailed deer which moved to private land west of the Monument in the spring of 1991. Of the 12 deer that currently use the Monument, 3 have used the Monument only on a seasonal basis.

White-tailed and mule deer increase their movement off the Monument to adjacent alfalfa fields in late summer and fall. In 1990, peak use of agricultural fields off the Monument by radio-collared deer occurred in September and October. Most does utilized alfalfa fields during the night and spent the daytime hours in either dense overstory vegetation just off the Monument or moved back onto the Monument.

Plant community was recorded for each of the radio-locations of deer on the Monument. Seasonal use of vegetative types on the Monument will be compared relative to forage availability, snow depths, and cover characteristics within the plant communities. Vegetative characteristics of plant communities were sampled within $\mathbf{4 5}$ representative sites during late June through July 1991 to describe forage availability at the peak of the growing season and relative cover characteristics during the summer. At each site, 20 microplots $\left(0.10 \mathrm{~m}^{2}\right)$ were placed at $2 \mathrm{~m}$ intervals along a transect and canopy coverage estimated by species. Every other plot $(n=10)$ was then clipped and separated into forbs, grasses, halfshrubs, and special forage species, dried at $70^{\circ} \mathrm{C}$ and weighed. Tree densities, canopy coverage, and DBH of tree species were determined within two $4 \times 25 \mathrm{~m}$ belt transects at each site. Shrubs densities and volumetric measurements (height $\mathrm{x}$ diameter) of shrubs were estimated in 20 circular plots $\left(4 \mathrm{~m}^{2}\right)$ located at $5 \mathrm{~m}$ interval along 2 transects at each site. Individuals were considered shrubs if they were $\leq 1.8 \mathrm{~m}$. Volumetric measurements were taken of at least 20 individual shrubs of each species, harvested, separated into leaves, current annual growth of stems, and old growth and weighed. Volumetric measurements will be used to estimate shrub biomass present at each site.

Seasonal changes in forage availability and forage consumption were monitored at 18 herbaceous plots and 13 shrub plots. Plots were selected to be representative of the particular plant communities on the Monument. Biomass was estimated using a point 
sampling (100 points) approach within $0.25 \mathrm{~m}^{2}$ microplots by plant form (green grass, green forb, dead grass, dead forb) inside 5 small, movable exclosures and at 5 random points outside the exclosures. Microplots were point sampled at beginning and the end of a 6-week sampling period to determine the change in biomass during the sampling period. After sampling, 5 plots were clipped at each site, vegetation was separated into plant form, dried at $70^{\circ} \mathrm{C}$ and weighed to determine relationships between points sampled and biomass. Along browse transects, 20 twigs of each species were marked within 3 height levels $(<0.5 \mathrm{~m},>0.5 \mathrm{~m}$ and $<1.5$ $\mathrm{m}$, and 1.5-1.8 m). Length, terminal and basal diameter of twigs, and diameter at point of browse and number of leaves were recorded for each twig. Twenty leaves and twigs of each species were collected each month, length and diameters measured, dried at $50^{\circ}$, and weighed to determine twig-lengthdiameter relationships.

Five pellets from each of 20 deer pellets groups were collected from each of the 4 quadrats of the Monument on a monthly basis to determine diet composition. Pellets were dried at $\leq 50^{\circ} \mathrm{C}$ for $>$ 3 days.

\section{$\checkmark \quad$ FUTURE WORK}

We will continue to monitor population densities and movements of radio-collared deer until the fall of 1992. We will initiate road counts in the fall of 1991 to evaluate this procedure as a tool for monitoring population trends. An additional $50(n=125)$ pellet group plots will be established this fall to increase the precision in our estimates. Snow markers will be reestablished in November to monitor snow depth within habitats on the Monument. Vegetation exclosure plots and browse transects will be surveyed this fall and again next spring. We will continue to collect fresh deer pellets on a monthly basis. Forage species will be collected bi-monthly during the winter. Collections will consist of the portions of plants that are observed to be cropped by deer. Dried forage collections will be analyzed for nutrient content and used to determine a nutritional carrying capacity. 